\title{
The correlation between students' curiosity and generic science skills in science learning
}

\author{
Herianto Herianto *, Insih Wilujeng \\ Universitas Negeri Yogyakarta. J1. Colombo No. 1, Yogyakarta, 55281, Indonesia. \\ * Corresponding Author. E-mail: herianto.2020@student.uny.ac.id
}

Received: 14 December 2020; Revised: 25 December 2020; Accepted: 30 December 2020

\begin{abstract}
Curiosity is an attitude and action that seeks to know more deeply and broadly from something learned and acts as a driving force for learning. Generic science skills are thinking skills in intellectual abilities resulting from a combination of scientific knowledge and skills based on scientific knowledge. The purpose of this study was to determine the correlation between curiosity and students' generic science skills in science learning. This study uses a quantitative approach to explore the correlation between the variables studied. The total sample was 64 junior high school students, who were selected by random cluster sampling. Measurement of students' curiosity was carried out using a questionnaire, while generic science skills used multiple-choice test questions. The data obtained were then analyzed using simple linear regression on SPSS to determine the correlation between the two variables. The results showed that curiosity correlated with students' generic science skills $(\mathrm{R}=.389)$, with the category "low positive correlation." The effect of curiosity on generic science skills is $15.1 \%$, while other variables influence the rest.
\end{abstract}

Keywords: curiosity, correlation, generic science skills, science learning

How to Cite: Herianto, H., \& Wilujeng, I. (2020). The correlation between students' curiosity and generic science skills in science learning. Jurnal Inovasi Pendidikan IPA, 6(2), 237-246. doi:https://doi.org/10.21831/jipi.v6i2.37382

\section{INTRODUCTION}

Education is an essential part of building a nation. The progress of a nation depends on the progress of its human resources. Education has a vital role in improving human resource quality, which is of high quality, smart, and competitive. The quality of human resources is characterized by the rapid development of individual thinking patterns, which can be in the form of creative, critical thinking, problem-solving, and decision-making abilities, where the prerequisite for mastering these thinking skills is mastery of generic science abilities (Sudarmin, 2009). Improving the quality of science education can be done through scientific thinking or the development of generic science skills (Liliasari, 2011). Through the improvement of generic science skills, human resources that have high competitiveness will be produced in the face of the 21st century.

Generic skills have been an element of educational policy and practice in the UK for more than 30 years. However, they are labelled variously, such as transferable skills, general skills, core skills, core skills, and essential skills (Huddleston \& Stanley, 2012). Generic skills are also referred to as core skills, core competencies, and generic attributes (Virtanen \& Tynjälä, 2018). Generic skills are employability skills that are used to apply knowledge (Kamsah, 2004). Based on this explanation, it can be seen that generic skills have several other different names.

Employers view "core skills" - numeracy, literacy, other generic skills, and practical experience as almost as essential as theoretical knowledge for professionals and skilled workers. Employers generally complain of a lack of generic skills, such as critical thinking, leadership, exporters, and foreign language skills (OECD, 2015). Genetic skills currently transversely penetrate higher education and primary and secondary education (Just \& Grahn, 2017). Generic skills are presently widely discussed in the field of education as well as work (Virtanen \& Tynjälä, 2018). Generic skills in science learning are known as generic science skills (Ramlawati et al., 2014). Generic science skills are a combination of scientific knowledge and skills (Khabibah et al., 2017).

Generic science skills are intellectual abilities resulting from a complex interaction between scientific knowledge and skills (Tawil \& Liliasari, 2014; Khabibah et al., 2017). Generic science skills 


\section{Jurnal Inovasi Pendidikan IPA, 6 (2), 2020 - 238}

Herianto Herianto, Insih Wilujeng

are skills that must be possessed to face the 21st century (Susanti et al., 2017). According to Haviz, Karomah, Delfita, Umar, \& Maris (2018), there is a need to review and reaffirm the integration of generic science skills in science learning because they are part of or similar to 21st-century skills. Students with generic skills have better graduate job prospects (Freudenberg, Brimble, \& Cameron, 2011). Generic science skills are also needed so that students can survive and improve their quality at a higher level or in the world of work (Sari et al., 2019). Through learning science, these generic skills can be trained on students so that they are ready to face future challenges.

There are nine aspects of generic science skills, namely direct observation, indirect observation, logical inference, mathematical modelling, symbolic language, concept-building, principle-abiding logic frameworks, causal laws, and awareness of scale (Liliasari et al., 2007; Tawil \& Liliasari, 2014; Maknun, 2015). Generic science skills are scientific thinking skills through observation, awareness of scale, symbolic language, inference logic, the law of cause and effect, logical framework, logical consistency, modelling, and abstraction (Yohana, Sudarmin, Wardani, \& Norashikin, 2018). The measurement of generic science skills in this study only uses test techniques.

Learning science as a way of thinking includes belief, curiosity, imagination, reasoning, causeand-effect relationships, self-examination and scepticism, objectivity, and open-heartedness (Liliasari, 2011). Based on this explanation, it can be said that curiosity is an essential part of learning science. Curiosity is a form of intrinsic motivation that is key in encouraging active learning and spontaneous exploration (Oudeyer et al., 2016). Students must have good curiosity because curiosity is an intrinsic motivation that has excellent potential to improve learning outcomes (Ostroff, 2016; Pluck \& Johnson, 2011). Curiosity can act as a driving force for learning, new insights, and innovation for individuals and society (Lindholm, 2018). The teacher has a responsibility to stimulate students' curiosity to have the driving force to continue learning.

Learners' generic science skills may also be related to other variables, such as curiosity. This is because curiosity is an incentive to know and understand nature (Collete \& Chiappetta, 1994). In Science, Curiosity is fundamental to scientific investigation and search (Gottfried et al., 2016). Curiosity in science is also an art and a skill: the art of seeing (paying attention) and the skill of asking questions (Whitesides, 2018). According to Jones \& Flint (2013), curiosity is the desire for new information or experiences that trigger reactions (exploration, use of information, or new media skills) and resolutions (either satisfied curiosity or individuals withdraw from situations that trigger curiosity). Curiosity has been recognized as a significant driving factor underlying and influencing positive and negative human behaviour (Shenaar-Golan \& Gutman, 2013). Based on some expert opinions, it can be concluded that curiosity is an attitude and action that seeks to find out more deeply and extensively from something being learned and acts as a driving force for learning.

According to Hayumuti et al. (2014), curiosity has three aspects: the desire to interact, the desire to know, and the desire to understand. The aspect of wanting to interact has two indicators, namely being interested in the material being taught and being curious about the material to be taught. The indicator on the aspect of wanting to know is to ask questions about learning material. The indicator of wanting to understand is conducting investigations to find answers to questions about learning material. Meanwhile, Weible \& Zimmerman (2016) explained that people who have curiosity when engaged in science practice build their scientific identity when they investigate, question, and manipulate, especially when participating socially with others.

According to Litman \& Jimerson (2004), a way to measure curiosity can be using a questionnaire, in which participants are instructed to report how they feel in general, by rating themselves on a commonly used 4-point frequency scale of $1=$ almost never, two $=$ sometimes, $3=$ often, and $4=$ almost always. The indicators of curiosity (curiosity) include (1) desire to explore information, (2) dare to ask questions, (3) adventure with information, and (4) willingness to explore information. Briefly, curiosity indicators are explorer, discovery, adventurous, and questioning (Raharja et al., 2018). The curiosity indicator is reinforced by Grossnickle's (2014) statement, which states that curiosity involves a regulatory system consisting of exploration, asking questions, or the desire to know what is currently unknown.

Curiosity plays an essential role in science learning, but it is still difficult to find reference sources that discuss the correlation between curiosity and generic science skills. This study's problem is how the correlation between curiosity and students' generic science skills is based on this background. This study 


\section{Jurnal Inovasi Pendidikan IPA, 6 (2), 2020 - 239}

Herianto Herianto, Insih Wilujeng

aimed to determine the correlation between curiosity and generic science skills of junior high school students.

\section{METHOD}

This research is descriptive quantitative. A total of 64 grade VII students (aged 12-14 years) who took science subjects on the topic of "Heat and Its Transfer" were involved in this research. The research was conducted in the first semester of the 2019/2020 school year at a public junior high school in Yogyakarta. Students were selected by using the cluster random sampling technique.

The instrument used in this study was a curiosity questionnaire sheet and a generic science skill test question sheet. The curiosity questionnaire consists of four indicators: the desire to explore information, ask questions (Grossnickle, 2014), be interested in the material being taught, and enthusiastically seek answers (Nasution, Harahap, \& Harahap, 2018). The statements contained in the questionnaire totalled 16 items, with details of eight positive statements and eight negative statements. After the questionnaire was validated and tested, the Cronbach's Alpha reliability coefficient was 0.872 .

The test questions used were multiple-choice questions totalling 35 items. In this study, there are six aspects of generic science skills that are measured, namely (1) indirect observation, (2) the law of cause and effect, (3) symbolic language, (4) mathematical modelling, (5) building concepts, and (6) abstraction. Experts have validated the generic science skills test questions used, and empirical test questions have been carried out. Based on the INFIT MNSQ value, all the items developed were between 0.87 and 1.13, so that all test items were declared valid. The result of the item estimate's reliability is 0.96 , and the reliability of the case estimate is 0.61 .

The generic science skill test questions and the curiosity questionnaire were given after the students had finished taking the science lesson on the topic "heat and its transfer." The data obtained were then analyzed to determine the correlation between the two variables using simple linear regression on SPSS 24. Besides, descriptive statistics were also carried out to determine general information on the curiosity score and generic science skills. The magnitude of the correlation between curiosity and generic science skills was then categorized or interpreted according to the guidelines in Table 1.

Table 1. Correlation Coefficient Interpretation

\begin{tabular}{ll}
\hline Size of Correlation & Interpretation \\
\hline .90 to 1.0 & A very high positive correlation \\
.70 to $<.90$ & High positive correlation \\
.50 to $<.70$ & Moderate positive correlation \\
.30 to $<.50$ & Low positive correlation \\
.00 to $<.30$ & Negligible correlation \\
\hline
\end{tabular}

(Agunbiade \& Ogunyinka, 2013)

\section{RESULTS AND DISCUSSION}

Simple linear regression is used to measure the influence of one independent variable or variable $\mathrm{X}$ on the dependent variable or variable $\mathrm{Y}$. The eligibility requirements that must be met when using simple linear regression are: (1) the number of samples used must be the same, (2) the number of independent variables (X) is one, (3) The residual value must be normally distributed, (4) there is a linear relationship between the independent variable $(\mathrm{X})$ and the dependent variable $(\mathrm{Y})$, and (5) there is no heteroscedasticity symptom. In this study, the number of samples used was the same for each variable. The number of independent variables is one, namely curiosity. The prerequisite test consisting of normality, linearity, and heteroscedasticity was carried out through SPSS. Tables 2, 3, and 4 show the prerequisite tests for normality, linearity, and heteroscedasticity.

Table 2. Normality Test Results

\begin{tabular}{lccc}
\hline & \multicolumn{3}{c}{ Shapiro-Wilk } \\
\cline { 2 - 4 } & Statistic & df & Sig. \\
\hline Generic science skills & .969 & 64 & .102 \\
Curiosity & .983 & 64 & .522 \\
\hline
\end{tabular}

Normality test using Shapiro-Wilk. Based on Table 2, it is known that the Sig. $>.05$, then the data is normally distributed. The significance value of the generic science skills variable was .102 , and the 
curiosity variable was .522 . Normally distributed data is one of the prerequisites that must be met before performing a simple linear regression analysis.

Table 3. Linearity test results

\begin{tabular}{|c|c|c|c|c|c|c|c|}
\hline \multicolumn{8}{|c|}{ ANOVA Table } \\
\hline & & & Sum of Squares & $\mathrm{df}$ & Mean Square & $\mathrm{F}$ & Sig. \\
\hline \multirow[t]{5}{*}{ Curiosity * GSS } & Between Groups & (Combined) & 1468.850 & 19 & 77.308 & 1.251 & .264 \\
\hline & & Linearity & 633.647 & 1 & 633.647 & 10.252 & .003 \\
\hline & & Deviation from Linearity & 835.203 & 18 & 46.400 & .751 & .741 \\
\hline & Within Groups & & 2719.507 & 44 & 61.807 & & \\
\hline & Total & & 4188.357 & 63 & & & \\
\hline
\end{tabular}

The decision on the linearity test is if the value of Deviation from Linearity Sig. > .05, then there is a significant linear relationship between the independent variable and the dependent variable. Based on Table 3, it is known that the significance value of deviation from linearity is .741 , so there is a significant linear relationship between curiosity and generic science skills.

Table 4. Heteroscedasticity test results

\begin{tabular}{|c|c|c|c|c|c|c|}
\hline \multicolumn{7}{|c|}{ Coefficients } \\
\hline & \multirow{2}{*}{ Model } & \multicolumn{2}{|c|}{ Unstandardized Coefficients } & \multirow{2}{*}{$\begin{array}{c}\text { Standardized Coefficients } \\
\text { Beta }\end{array}$} & \multirow{2}{*}{$\mathrm{t}$} & \multirow{2}{*}{ Sig. } \\
\hline & & $\mathrm{B}$ & Std. Error & & & \\
\hline \multirow[t]{2}{*}{1} & (Constant) & 8.919 & 6.658 & & 1.340 & .185 \\
\hline & Curiosity & .045 & .124 & .046 & .359 & .721 \\
\hline
\end{tabular}

a. Dependent Variable: Abs_RES

Based on the results in Table 4, the sig value is obtained $>.05$; then there are no symptoms of heteroscedasticity. All prerequisite tests have been fulfilled so that they can be continued in a simple linear regression analysis. This study's results are in the form of a relationship between students' generic science skills and curiosity. The regression model test used is simple linear regression; in the hypothesis test, the correlation between curiosity (X) and generic science skills (Y).

Table 5. Descriptive Statistics

\begin{tabular}{lccccc}
\hline & $\mathrm{N}$ & Minimum & Maximum & Mean & Std. Deviation \\
\hline GSS & 64 & 20.00 & 82.86 & 52.7678 & 15.08401 \\
Curiosity & 64 & 38.47 & 72.88 & 52.9727 & 8.15364 \\
\hline
\end{tabular}

Table 5 shows the descriptive statistics of the generic science skills and the curiosity of students. Table 5 only shows the general results of the generic science skills and students' curiosity, consisting of the minimum, maximum, mean, and standard deviation. Table 1 shows that the minimum score for generic science skills is still very low, only 20.00 . This shows that there are still students who have very low generic science skills scores. The minimum score for curiosity is also still very low, at only 38.47.

Table 6. Model summary

\begin{tabular}{lcccc}
\hline Model & $\mathrm{R}$ & $\mathrm{R}$ Square & Adjusted R Square & Std. Error of the Estimate \\
\hline 1 & $.389^{\mathrm{a}}$ & .151 & .138 & 14.00785 \\
\hline
\end{tabular}

a. Predictors: (Constant), curiosity

Based on Table 6, it is known that the value of $\mathrm{R}=.389$ means that the correlation between the curiosity variable $(\mathrm{X})$ and generic science skills $(\mathrm{Y})$ is .389 . From the output in Table 6 , the coefficient of determination $\left(\mathrm{R}^{2}\right)$ is .151 , which implies that the influence of the independent variable (curiosity) on the dependent variable (generic science skills) is $15.1 \%$, while other variables influence the rest.

Table 7. ANOVA

\begin{tabular}{llccccc}
\hline & Model & Sum of Squares & df & Mean Square & F & Sig. \\
\hline 1 & Regression & 2168.593 & 1 & 2168.593 & 11.052 & $.001^{\mathrm{b}}$ \\
Residual & 12165.635 & 62 & 196.220 & & \\
& Total & 14334.229 & 63 & & & \\
\hline
\end{tabular}

a. Dependent Variable: GSS

b. Predictors: (Constant), Curiosity

Table 7 shows the ANOVA output, which reports how well the regression equation fits into the data (i.e., predicts the dependent variable). From this output, it can be seen that the significance level is 


\section{Jurnal Inovasi Pendidikan IPA, 6 (2), 2020 - 241}

Herianto Herianto, Insih Wilujeng

$.001<.05$, which indicates that the overall regression model is statistically significant in predicting the generic science skill variable.

Table 8. Coefficients

\begin{tabular}{|c|c|c|c|c|c|}
\hline \multirow[b]{2}{*}{ Model } & \multicolumn{2}{|c|}{ Unstandardized Coefficients } & \multirow{2}{*}{$\begin{array}{c}\text { Standardized Coefficients } \\
\text { Beta } \\
\end{array}$} & \multirow[b]{2}{*}{$\mathrm{l}$} & \multirow[b]{2}{*}{ Sig. } \\
\hline & $\mathrm{B}$ & Std. Error & & & \\
\hline 1 (Constant) & 14.651 & 11.599 & & 1.263 & .211 \\
\hline Curiosity & .720 & .216 & .389 & 3.324 & .001 \\
\hline
\end{tabular}

a. Dependent Variable: GSS

In general, the simple linear regression equation formula is $\mathrm{Y}=\mathrm{a}+\mathrm{bX}$. Meanwhile, to determine the value of the regression coefficient, we can refer to the output in the coefficients table. "a" = constant number of unstandardized coefficients; in this case, the value is 14,651. This figure is a constant number, which means that if there is no curiosity $(\mathrm{X})$, then the consistent value of generic science skills $(\mathrm{Y})$ is $14,651 . " \mathrm{~b} "=\mathrm{a}$ number of the regression coefficient, the value is 0.720 . This figure means that with every $1 \%$ increment of curiosity $(\mathrm{X})$, the generic science skill $(\mathrm{Y})$ will increase by 0.720 . Because the regression coefficient is positive (+), it can be said that curiosity $(\mathrm{X})$ has a positive effect on generic science skills (Y). Based on Table 8. the regression equation can be written $\mathrm{Y}=14,651+0.720 \mathrm{X}$. From the output of Table 8, it can be seen that the significance value of $.001<.05$, then there is a significant effect of curiosity (X) on generic science skills (Y).

Simple regression analysis showed that curiosity correlated with students' generic science skills $(\mathrm{R}=.389)$. According to Agunbiade \& Ogunyinka (2013), the magnitude of the correlation $(\mathrm{R}=.389)$ of curiosity and generic science skills is in the category of "low positive correlation." Although the correlation between curiosity and generic science skills is low, a positive correlation shows that if students' curiosity is high, generic science skills also tend to be high. The effect of curiosity on generic science skills is $15.1 \%$, while other variables influence the rest. There is a significant effect of curiosity on students' generic science skills, as seen from the sig value. <.05. Referring to the previous discussion, we can conclude that curiosity (X) has a positive effect on generic science skills (Y) with a total effect of $15.1 \%$. This positive effect means that students' increasing curiosity will affect the increase in these students' generic science skills.

This study indicates that it is necessary to increase students' curiosity if they want to improve students' generic science skills. The results showed that the average score on generic science skills was 52.7678 , while the average score on curiosity was 52.9727. The two variables' average score shows that students' scores are still not optimal on generic science and curiosity skills. Both of these variables have almost the same average score, and it is also known that they have a significant correlation. If the teacher can increase the students 'curiosity, the students' generic science skills will also increase, although the effect exerted by curiosity is only about $15.1 \%$ (seen from the $\mathrm{R}$ square). The teacher can predict students' generic science skills if they have data about curiosity, namely, using the regression equation, $\mathrm{Y}=14.651+0.720 \mathrm{X}$. Based on the regression equation, if there is no curiosity $(\mathrm{X})$, the consistent value of generic science skills (Y) is 14.651 .

Based on our research, the average generic science skills score of junior high school students was only 52,7678, which according to Khabibah et al. (2017), an average score of 52,7678 is included in the "Moderate" category. Our results regarding the mean score of generic science skills are almost the same as the study conducted by Murti et al. (2018), namely 46.02 (in the control class). The research results by Murti et al. (2018) show that junior high school students have generic science skills in the "Moderate" category if learning is carried out as usual without special treatment. Another study conducted by Khabibah et al. (2017) at one of the State Madrasah Aliyah in Surakarta showed that students' generic science skills were in the "Moderate" category, with an average score of $53.43 \%$. These results indicate that both junior high school and high school / Madrasah Aliyah students have almost the same generic science skills; namely, they are still in the "Moderate" category. The generic science skills of students who are still in the Moderate category must be improved, at least to the "Good" category.

Students must have high curiosity in the learning process because curiosity is an intrinsic motivation that can improve learning outcomes (Pluck \& Johnson, 2011; Ostroff, 2016). It is known that there is a strong correlation between learning outcomes and generic science skills (Tuapattinaya \& Rumahlatu, 2018). Our results provide new information that curiosity correlates with generic science 


\section{Jurnal Inovasi Pendidikan IPA, 6 (2), 2020 - 242}

Herianto Herianto, Insih Wilujeng

skills. We still have not found any research results that discuss the correlation between curiosity and generic science skills, so we cannot compare it with other studies.

Based on our research, it is known that the average curiosity score of students is 52.9727 . According to Widoyoko (2009), the average score of 52.9727 is in the "Moderate" category if referring to the categorization. The results of our research regarding the curiosity profile of students are in line with research conducted by Fuadati \& Wilujeng (2019), where the average curiosity score of junior high school students was 48.05 (in the control class), which means that it is in the "Moderate" category. This means that junior high school students' curiosity profile is still in the "Moderate" category, so it needs to be improved. Curiosity students who are only in the "Moderate" category affect the generic science skills of students. As previously explained, it is known that there is a positive correlation between curiosity and generic science skills, although the correlation between the two is in a low category $(\mathrm{R}=$ .389). This study indicates that the two variables we studied, namely curiosity and generic science skills of students, have the same category, namely moderate.

Recent studies have shown that curiosity significantly improves learning and information retention over time (Gruber \& Ranganath, 2019). Curiosity children are positively related to their acquisition of knowledge (van Schijndel, Jansen, \& Raijmakers, 2018); knowledge is part of science's generic skills. This is following the understanding that generic science skills are intellectual abilities resulting from a combination of a complex interaction between scientific knowledge and skills (Tawil \& Liliasari, 2014; Khabibah et al., 2017). Some of these opinions indicate that curiosity does have a relationship with students' generic skills. The correlation between these two variables has been proven in our study.

Curiosity is a miracle of the human mind that acts as a driving force for learning, new insights, and innovation for individuals and society (Lindholm, 2018). The role of curiosity is to mentor individuals, so it is only natural that curiosity correlates with generic science skills. Students who have good curiosity will learn the symbolic language and mathematical modelling, which are aspects of generic science skills. Curiosity is a form of intrinsic motivation that is key in encouraging active learning and spontaneous exploration (Oudeyer et al., 2016). Students who have curiosity will have the urge to explore spontaneously to enable students to learn about indirect observation, the law of cause and effect, construct concepts, and abstraction. Exploring in question can be in direct exploration in nature or exploration of information through various information sources. According to Ostroff (2016), curiosity releases dopamine, bringing pleasure and improving observation and memory. An increase in observation and memory in a person will undoubtedly positively affect aspects of generic science skills such as indirect observation.

The importance of generic science skills for students was conveyed by Nastiti, Rahardjo, Elfi Susanti, \& Perdana (2018), who stated that generic science skills are essential for students to solve every learning problem process and daily life. Meanwhile, Cain (2019) explains that curiosity is a trait that encourages people to ask exploratory questions and find creative ways to solve problems. Based on the expert's opinion, it can be said that curiosity acts as an impetus for someone to find creative ways to solve problems. At the same time, generic science skills are needed to solve every problem. This means that curiosity only acts as a driving force, whereas generic science skills are used to solve problems in everyday life. Therefore, curiosity has a positive correlation with generic science skills.

Our results show that curiosity correlates with generic science skills, where curiosity positively affects the improvement of students' generic science skills. As explained by experts, curiosity acts as an incentive for a person to learn, in the context of our research, learning about generic science skills. Educators need to continue to increase students' curiosity if they want to improve students' generic science skills. Today's primary goal of science education is to increase children's curiosity about nature and foster positive science (Kesner Baruch et al., 2016). Although curiosity affects generic science skills, many other factors also affect generic science skills, so further research is needed to find these other factors. We suggest that future research be carried out to simultaneously increase curiosity and generic science skills because these two variables are essential in science learning.

\section{CONCLUSION}

Based on the research and discussion results, it can be concluded that curiosity correlates with students' generic science skills $(\mathrm{R}=.389)$, with the category "low positive correlation." The effect of 


\section{Jurnal Inovasi Pendidikan IPA, 6 (2), 2020 - 243}

Herianto Herianto, Insih Wilujeng

curiosity on generic science skills is $15.1 \%$, while other variables influence the rest. Students' generic science skills can increase if students' curiosity also increases because both have a positive correlation. Our results also show that students' curiosity and generic science skills are in the "Moderate" category, so they need to be improved. We suggest that future research should be carried out to simultaneously increase curiosity and generic science skills because these two variables are essential in science learning.

\section{REFERENCES}

Agunbiade, D. A., \& Ogunyinka, P. I. (2013). Effect of correlation level on the use of an auxiliary variable in double sampling for regression estimation. Open Journal of Statistics, 03(05), 312318. https://doi.org/10.4236/ojs.2013.35037

Cain, J. (2019). We should pay more attention to student curiosity. Currents in Pharmacy Teaching and Learning, 11(7), 651-654. https://doi.org/10.1016/j.cptl.2019.03.001

Collete, A. T., \& Chiappetta, E. L. (1994). Science instruction in the middle and secondary schools (Third). Macmillan publishing company.

Freudenberg, B., Brimble, M., \& Cameron, C. (2011). WIL and generic skill development: The development of business students ' generic skills through work- integrated learning. Asia- Pacific Journal of Cooperative Education, 12(2), 79-93. https://papers.ssrn.com/sol3/papers.cfm?abstract_id=1851169

Fuadati, M., \& Wilujeng, I. (2019). Web-lembar kerja peserta didik IPA terintegrasi potensi lokal pabrik gula untuk meningkatkan rasa ingin tahu peserta didik. Jurnal Inovasi Pendidikan IPA, 5(1), 98 108. https://doi.org/10.21831/jipi.v5i1.24543

Gottfried, A. E., Preston, K. S. J., Gottfried, A. W., Oliver, P. H., Delany, D. E., \& Ibrahim, S. M. (2016). Pathways from parental stimulation of children's curiosity to high school science course accomplishments and science career interest and skill. International Journal of Science Education, 38(12), 1-23. https://doi.org/10.1080/09500693.2016.1220690

Grossnickle, E. M. (2014). Disentangling curiosity: dimensionality, definitions, and distinctions from interest in educational contexts. Educational Psychology Review, 28(1), 23-60. https://doi.org/10.1007/s10648-014-9294-y

Gruber, M. J., \& Ranganath, C. (2019). How curiosity enhances hippocampus-dependent memory: the prediction, appraisal, curiosity, and exploration (PACE) framework. Trends in Cognitive Sciences, 23(12), 1014-1025. https://doi.org/10.1016/j.tics.2019.10.003

Haviz, M., Karomah, H., Delfita, R., Umar, M. I. A., \& Maris, I. M. (2018). Revisting generic science skill as 21st century skills on biology learning. Jurnal Pendidikan IPA Indonesia, 7(3), 355-363. https://doi.org/10.15294/jpii.v7i3.12438

Hayumuti, Paranimmita, R., \& Setyo, G. (2014). Mengasah rasa keingintahuan siswa melalui penggunaan multimedia tema selalu berhemat energi. Prosiding Seminar Nasional KSDP Prodi S1 PGSD "Konstelasi Pendidikan Dan Kebudayaan Indonesia Di Era Globalisasi.

Huddleston, P., \& Stanley, J. (2012). Work-related teaching and learning. Routledge Taylor\& Francis Group.

Jones, J. B., \& Flint, L. J. (2013). The creative imperative: school librarians and teachers cultivating curiosity together. ABC-CLIO, LLC.

Just, E., \& Grahn, W. (2017). Theories of affect and concepts in generic skills education: adventurous encounters. Cambridge Scholars Publishing.

Kamsah, M. Z. (2004). Developing generic skills in classroom environment: Engineering students' perspective. Conference on Engineering Education (CEE 2004), 1-6.

Kesner Baruch, Y., Spektor-Levy, O., \& Mashal, N. (2016). Pre-schoolers' verbal and behavioral responses as indicators of attitudes and scientific curiosity. International Journal of Science and Mathematics Education, 14(1), 125-148. https://doi.org/10.1007/s10763-014-9573-6

Khabibah, E. N., Masykuri, M., \& Maridi. (2017). The analysis of generic science skills of high school students. International Conference on Teacher Training and Education, 158, 251-256. https://doi.org/10.2991/ictte-17.2017.48 


\section{Jurnal Inovasi Pendidikan IPA, 6 (2), 2020 - 244}

Herianto Herianto, Insih Wilujeng

Liliasari, Setiawan, A., \& Widodo, A. (2007). Model-model pembelajaran berbasis teknologi informasi untuk meningkatkan keterampilan generik sains dan berpikir tingkat tinggi pebelajar. In Penelitian HPTP. Universitas Pendidikan Indonesia.

Liliasari. (2011). Membangun masyarakat melek sains berkarakter bangsa melalui pembelajaran. Seminar Nasional Pendidikan IPA Tahun 2011, 1-8. http://staffnew.uny.ac.id/upload/132319972/penelitian/Prosiding Seminar Nasional IPA III tahun 2011.pdf

Lindholm, M. (2018). Promoting curiosity?: possibilities and pitfalls in science education. Science and Education, 27(9-10), 987-1002. https://doi.org/10.1007/s11191-018-0015-7

Litman, J. A., \& Jimerson, T. L. (2004). The measurement of curiosity as a feeling of deprivation. $\begin{array}{llll}\text { Journal of Personality } & \text { Assessment, }\end{array}$ https://doi.org/https://doi.org/10.1207/s15327752jpa8202_3

Maknun, J. (2015). The implementation of generative learning model on physics lesson to increase mastery concepts and generic science skills of vocational students. American Journal of Educational Research, 3(6), 742-748. https://doi.org/10.12691/EDUCATION-3-6-12

Murti, D. H., Prasetyo, Z. K., \& Wilujeng, I. (2018). The effectiveness of a local potentiality based learning video about distillation clove leaf essential oil to improve generic skill. Journal of Physics: Conference Series, 1097(1). https://doi.org/10.1088/1742-6596/1097/1/012005

Nastiti, D., Rahardjo, S. B., Elfi Susanti, V. H., \& Perdana, R. (2018). The need analysis of module development based on search, solve, create, and share to increase generic science skills in chemistry. Jurnal Pendidikan IPA Indonesia, 7(4), 428-434. https://doi.org/10.15294/jpii.v7i4.12393

Nasution, D., Harahap, P. S., \& Harahap, M. (2018). Development instrument's learning of physics through scientific inquiry model based batak culture to improve science process skill and student's curiosity. Journal of Physics: Conference Series, 970(1). https://doi.org/10.1088/17426596/970/1/012009

OECD. (2015). Education in Indonesia: rising to the challenge. OECD.

Ostroff, W. L. (2016). Cultivating curiosity in K-12 classrooms. ASCD.

Oudeyer, P.-Y., Gottlieb, J., \& Lopes, M. (2016). Intrinsic motivation, curiosity, and learning: Theory and applications in educational technologies. Progress in Brain Research, 229, 257-284. https://doi.org/http://dx.doi.org/10.1016/bs.pbr.2016.05.005

Pluck, G., \& Johnson, H. (2011). Stimulating curiosity to enhance learning. Education Science and Psychology, 2(19), 24-31. https://doi.org/10.1017/CBO9781107415324.004

Raharja, S., Wibhawa, M. R., \& Lukas, S. (2018). Mengukur rasa ingin tahu siswa [measuring students' curiosity]. Polyglot: Jurnal Ilmiah, 14(2), 151-164. https://doi.org/10.19166/pji.v14i2.832

Ramlawati, R., Liliasari, L., Martoprawiro, M. A., \& Wulan, A. R. (2014). The effect of electronic portfolio assessment model to increase of students generic science skills in practical inorganic chemistry. Journal of Education and Learning (EduLearn), 8(3), 179-186. https://doi.org/10.11591/edulearn.v8i3.260

Sari, I. M., Ahmad, S. F., \& Amsor. (2019). Peningkatan keterampilan generik sains pada materi tata surya melalui pembelajaran berbantuan aplikasi solar system scope untuk siswa SMP. Journal of Teaching and Learning Physics, 4(2), 1-17. https://doi.org/10.15575/jotalp.v4i2.4294

Shenaar-Golan, V., \& Gutman, C. (2013). Curiosity and the cat: teaching strategies that foster curiosity. Social Work with Groups, 36(4), 349-359. https://doi.org/10.1080/01609513.2013.769076

Sudarmin. (2009). Pembelajaran kimia terintegrasi kemampuan generik sains untuk meningkatkan kemampuan berpikir calon guru. Jurnal Pendidikan Matematika Dan Sains, 1, 37-44. https://doi.org/10.21831/jpms.v14i1.175

Susanti, Prasetyo, Z. K., \& Wilujeng, I. (2017). Comparative effectiveness of science integrated learning local potential of essential oil clove leaves in improving science generic skills. International Journal of Environmental and Science Education, 11(8), 1817-1827. http://www.ijese.net/makale_indir/IJESE_1944_article_59eb1387afb22.pdf 


\section{Jurnal Inovasi Pendidikan IPA, 6 (2), 2020 - 245}

Herianto Herianto, Insih Wilujeng

Tawil, M., \& Liliasari. (2014). Keterampilan-keterampilan sains dan implementasinya dalam pembelajaran IPA. Badan Penerbit UNM.

Tuapattinaya, P. M. ., \& Rumahlatu, D. (2018). The correlation between generic science skill and biology learning results of public junior high schools in Ambon using scientific approach. Journal of Education and Learning (EduLearn), 12(2), 297-305. https://doi.org/10.11591/edulearn.v12i2.7319

Van Schijndel, T. J. P., Jansen, B. R. J., \& Raijmakers, M. E. J. (2018). Do individual differences in children's curiosity relate to their inquiry-based learning? International Journal of Science Education, 40(9), 1-20. https://doi.org/10.1080/09500693.2018.1460772

Virtanen, A., \& Tynjälä, P. (2018). Factors explaining the learning of generic skills: a study of university students' experiences. Teaching in Higher Education, 24(7), 1-15. https://doi.org/10.1080/13562517.2018.1515195

Weible, J. L., \& Zimmerman, H. T. (2016). Science curiosity in learning environments: developing an attitudinal scale for research in schools, homes, museums, and the community. International Journal of Science Education, 38(8), 1235-1255. https://doi.org/10.1080/09500693.2016.1186853

Whitesides, G. M. (2018). Curiosity and Science. Angewandte Chemie - International Edition, 57(16), 1-8. https://doi.org/10.1002/anie.201800684

Widoyoko, E. P. (2009). Evaluasi program pembelajaran [evaluation of learning programs]. Pustaka Pelajar.

Yohana, I., Sudarmin, S., Wardani, S., \& Norashikin, S. (2018). The generic science skill profile of fourth grade students on acid and base topic in guided inquiry learning model. International Journal of Active Learning, 3(2), 110-116. https://journal.unnes.ac.id/nju/index.php/ijal/article/view/13485 